\title{
Minimal changes of serum creatinine in the early postoperative period predict prognosis in patients after cardiac surgery
}

\author{
MH Bernardi ${ }^{*}$, R Ristl $^{2}$, M Mouhieddine $^{1}$, M Hiesmayr $^{1}$, A Lassnigg $^{1}$ \\ From ESICM LIVES 2015 \\ Berlin, Germany. 3-7 October 2015
}

\section{Introduction}

Preoperative renal insufficiency is an important predictor of mortality after cardiac surgery and the association between small serum creatinine ( $\mathrm{SCr}$ ) changes within 48 hours after cardiac surgery and mortality has been demonstrated. ([1]) Further it has been shown recently that a preoperative elevated $\mathrm{SCr}$ is a predictor for worse outcome after cardiac surgery too. ([2])

\section{Objectives}

The aim of the present investigation was the association between small $\mathrm{SCr}$ changes ( $\Delta \mathrm{Crea}$ ) early after surgery on 30-day mortality in patients below and above the $\mathrm{SCr}$ cut-off of $1.3 \mathrm{mg} . \mathrm{dL}^{-1}$ where mortality increases.

\section{Methods}

Elective adult cardiac surgical patients between 1997 and 2001 at the Medical University of Vienna were included. The cohort was split into two groups: Patients with an elevated $\mathrm{SCr}>1.3 \mathrm{mg} \cdot \mathrm{dL}^{-1}$ and $\leq 1.3 \mathrm{mg} \cdot \mathrm{dL}^{-1}$. Within 120 minutes after end of surgery, the $\Delta$ Crea between the first measured $\mathrm{SCr}$ and the baseline $\mathrm{SCr}$ value was calculated for each patient. Mortality rates were calculated stepwise in $0.1 \mathrm{mg} . \mathrm{dL}^{-1}$ intervals of $\Delta$ Crea.
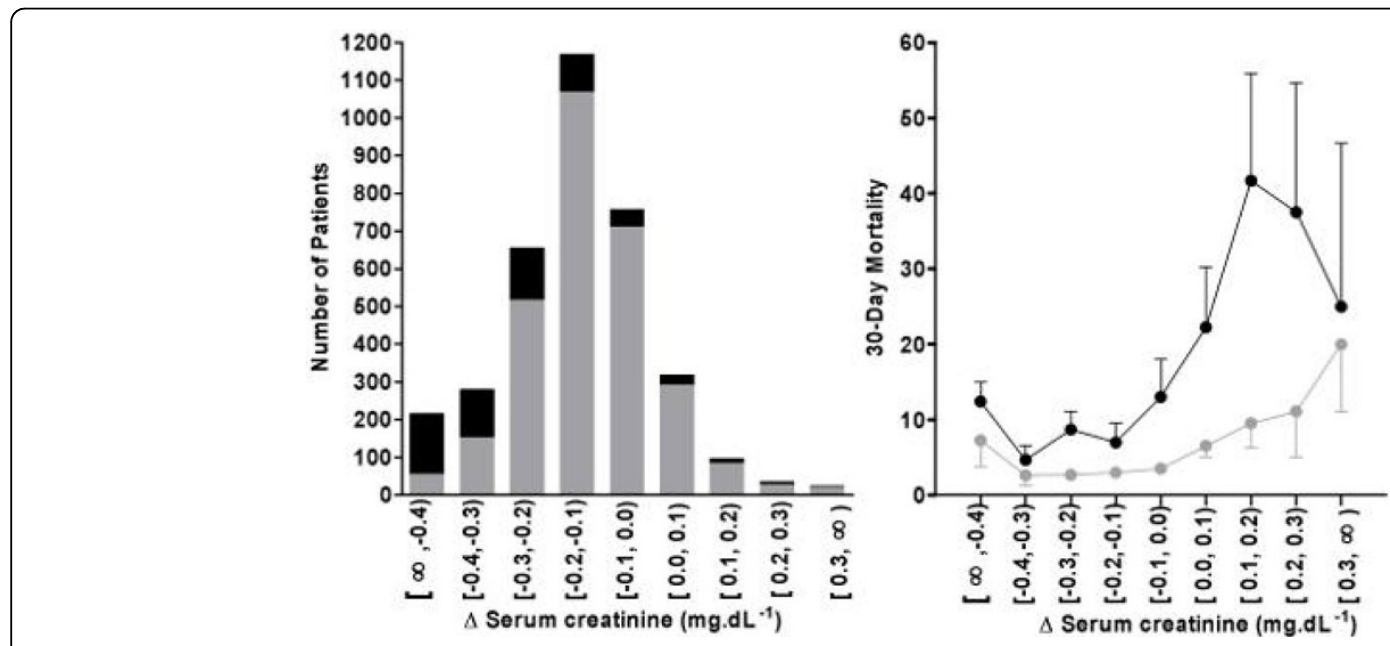

Figure 1

${ }^{1}$ Medical University of Vienna, Cardiothoracic and Vascular Anaesthesia \&

Intensive Care, Vienna, Austria

Full list of author information is available at the end of the article

(c) 2015 Bernardi et al.; This is an Open Access article distributed under the terms of the Creative Commons Attribution License (http:// creativecommons.org/licenses/by/4.0), which permits unrestricted use, distribution, and reproduction in any medium, provided the original work is properly cited. 


\section{Results}

A total of 3549 patients (1221 women) with a mean age of 64.5 years (range, 18 to 92) were investigated, 624 patients had an elevated $\mathrm{SCr}>1.3 \mathrm{mg} \cdot \mathrm{dL}^{-1}$. Within 30 days $5 \%(n=179)$ died. Mortality in patients with elevated $\mathrm{SCr}$ and a negative $\Delta$ Crea or equal 0 was $9 \%(n=573)$, while mortality increases in patients with an increasing $\Delta$ Crea to $31 \%(n=51)$.

An increase in mortality (12\%) was found in the group with the most pronounced fall $[\infty,-0.4)$. The relation of mortality to $\Delta$ Crea is shown in figure 1 ( $\mathrm{SCr}>1.3 \mathrm{mg}$. $\mathrm{dL}^{-1}$ marked in black and $\leq 1.3 \mathrm{mg} \cdot \mathrm{dL}^{-1}$ marked in grey).

\section{Conclusions}

Hemodilution occurs in patients operated on cardiopulmonary bypass (CPB). A decrease in $\mathrm{SCr}$ is the reaction to fluid supply and blood loss especially when preoperative $\mathrm{SCr}$ is elevated. Our findings suggest that in these patients with an elevated $\mathrm{SCr}$, even a minimal increase after $\mathrm{CPB}$ accordingly to the preoperative $\mathrm{SCr}$ is associated with a higher rate of death and may be a marker of diffuse organ injury. Furthermore large decreases of $\Delta$ Crea directly after cardiac surgery worsen outcome in this patient group drastically. A renoprotective postoperative course is recommended.

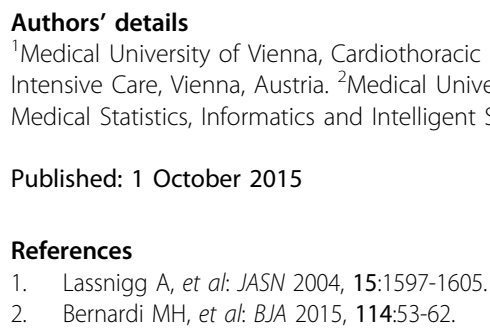

Published: 1 October 2015

\section{References}

1. Lassnigg A, et al: JASN 2004, 15:1597-1605.

2. Bernardi $\mathrm{MH}$, et al: BJA 2015, 114:53-62.

doi:10.1186/2197-425X-3-S1-A636

Cite this article as: Bernardi et al.: Minimal changes of serum creatinine in the early postoperative period predict prognosis in patients after cardiac surgery. Intensive Care Medicine Experimental 2015 3(Suppl 1):A636.

\section{Submit your manuscript to a SpringerOpen ${ }^{\mathcal{D}}$ journal and benefit from:}

- Convenient online submission

- Rigorous peer review

- Immediate publication on acceptance

- Open access: articles freely available online

- High visibility within the field

- Retaining the copyright to your article

Submit your next manuscript at $>$ springeropen.com 